\title{
INTEGRATED PROJECT DELIVERY WITH BIM: A METHODICAL APPROACH WITHIN THE UK CONSULTING SECTOR
}

\author{
SUBMITTED: October 2021 \\ REVISED: October 2021 \\ PUBLISHED: November 2021 \\ GUEST EDITORS: Nashwan Dawood, Farzad Pour Rahimian \\ DOI: $10.36680 /$ j.itcon.2021.049
}

\section{Prasenjit Dalui}

School of Natural and Built Environment, Queen's University Belfast, UK

pdalui01@qub.ac.uk

Faris Elghaish, PhD

School of Natural and Built Environment, Queen's University Belfast, UK

F.elghaish@qub.ac.uk, https://orcid.org/0000-0002-7558-6291

Tara Brooks, PhD

School of Natural and Built Environment, Queen's University Belfast, UK

T.Brooks@qub.ac.uk, https://orcid.org/0000-0003-3734-4416

\section{Stephen McIlwaine, PhD}

School of Natural and Built Environment, Queen's University Belfast, UK

S.McIlwaine@qub.ac.uk, https://orcid.org/0000-0001-5245-6737

SUMMARY: The aim of this study is to identify the advantages and limitations in the implementation of the Building Information Modelling (BIM) and Integrated Project Delivery (IPD) in the UK consulting sector. A literature review critically analyses the existing literature, (including online articles and publications owing to the current and fast-moving nature of the topic in question). Next, a qualitative research approach was employed through interviews which targeted BIM professionals across the AEC sector in the UK. Barriers to BIM were found to include lack of enthusiasm for potential opportunities for BIM and IPD. Cultural factors which act against BIM and IPD implementation include, willingness to adopt BIM environment, software cost, high-end user maintenance cost. Furthermore, a need was determined for UK government support and encouragement for the use of BIM and IPD for smaller projects. This study recommends that schools take steps to improve career advice and guidance for students in relation to construction, specifically increasing awareness of the opportunities available related to BIM and working professionals to increase awareness of and employment in BIM through training and apprentices as appropriately. Finally, the paper concludes that BIM and IPD should be more widely adopted within AEC industries in the UK to maximise benefits from both systems.

KEYWORDS: IPD, BIM, Barriers and Challenges, Collaborative approach, emerging technologies

REFERENCE: Prasenjit Dalui, Faris Elghaish, Tara Brooks, Stephen McIlwaine (2021). Integrated Project Delivery with BIM: A Methodical Approach Within the UK Consulting Sector. Journal of Information Technology in Construction (ITcon), Special issue: 'Construction 4.0: Established and Emerging Digital Technologies within the Construction Industry (ConVR 2020)', Vol. 26, pg. 922-935, DOI: 10.36680/j.itcon.2021.049

COPYRIGHT: (C) 2021 The author(s). This is an open access article distributed under the terms of the Creative Commons Attribution 4.0 International (https://creativecommons.org/licenses/by/4.0/), which permits unrestricted use, distribution, and reproduction in any medium, provided the original work is properly cited. 


\section{INTRODUCTION}

Integrated Project Delivery (IPD) and Building Information Modelling (BIM) has developed exponentially over the past years in AEC organisations (Owen et al., 2010). Recently, there has been an transition of focus on innovative methods of project delivery (Pal \& Nassarudin, 2020). Traditional processes of project handling such as Design Bid Build, Design Bid, Design build, or Turnkey project delivery methods are falling out of favour due to their inherent characteristics (Adamtey, 2021). Complications for instance, difficulty to ensure full coordination uring certain project phases, or owner risk for design faults, contracting limitations, time-cost-quality, are only a few drawbacks which have previously been identified(Eastman et al., 2008). Integrated Project Delivery (IPD) and Building Information Modelling (BIM) in combination emerge as potential improvements for project management, due to their ability to aid managing a project in a disciplined way with best oriented outcomes from a project for all parties, including stakeholders, owners, contractors, construction managers, designers and consulting firms (Cassino et al., 2014).

BIM working environment and IPD methods have been developed to work in 'hand in hand' for an improved efficient way for infrastructure project's management, to increase profit from application of both systems in a project at an early stage (Omoregie \& Turnbull, 2016a). Construction companies around the global are getting benefits from BIM implementation on their IPD projects (Zaini et al., 2020). Adopting BIM within the industry in the UK is gradually increasing due to its evident advantages (Omoregie \& Turnbull, 2016b). Sustainability assessments are aided with the use of BIM software tools. BSA methods- LEED, BREEAM and SBTool, and using BIM tools during the design phase are providing significant sustainability advantages with the use of BIM software in any IPD projects (Carvalho et al., 2020). If BIM is implemented in all the stages of the project, it supports better project outcomes in terms of design quality, data sharing ability, decrease of costs, decrease in design errors, faster completion, and improving energy productivity. (Doumbouya et al., 2016).

For the past 20 years, attempts have been made to implement BIM with IPD projects or IPD-like projects (Kent et al., 2010). Integrated project delivery (IPD) is a contemporary approach, its primary requirements are the inclusion and collaboration of the major project-participants from the introductory stages of the project, which can be aided through use of building information modelling (BIM) (Bilge \& Yaman, 2021; Sheikhkhoshkar et al., 2019).

This is an interesting era of IPD application in projects, particularly in combination with BIM technology at an early stage(Goulding et al., 2014 ; Autodesk., 2020). Building information modelling (BIM) innovation gives an exact computerized virtual display of the proposed building or infrastructure, with additional functionality such as clash detection (Bernstein \& Jones, 2009).

It has revolutionalised construction in the last few decades. With the use of more sophisticated techniques such as 4D BIM changes are continuing to evolve (Elghaish et al., 2020). BIM+ integrates visualisation and stimulation, co-location and collaboration allows IPD teams to integrate process in AEC projects (Fischer et al., 2017).

With all the above in the mind, the 1 aim of this study is to investigate the advantages and limitations currently existing with the implementation of BIM in combination with IPD methodology in AEC projects in the UK within the UK consulting sector. This will be achieved through (1) evaluating the existing research for IPD and BIM advantages in the UK construction field, (2) exploring the barriers to using with the IPD model with BIM implementation, and (3) exploring success factors to overcome the barriers in implementing BIM and IPD within the construction and consulting sectors in the UK.

\section{CONCEPTUAL BACKGROUND}

\subsection{Integrated Project Delivery}

Construction projects are represented with certain features; each is one of a kind. Projects have differing frameworks, teams, constraints and risks. A project team is said to work within the agreed plans and budgets to create a particular result (Forbes \& Ahmed, 2010).

The American Institute of Architects (AIA) characterize IPD as "a project conveyance approach that coordinating individuals, frameworks, commerce structures, and hones into a handle that collaboratively tackles the gifts and experiences of all venture members to optimize extend comes about, increment esteem to the proprietor, diminish squander, and maximize effectiveness through all stages of plan, creation, and development" (AIA California Council, 2007).It combines key people and skills from the developers, administrators, manufacturers, clients and 
fabricators to clients and planners prior to tender (Lee et al., 2014). This permits the production of a project plan that's optimised for quality, aesthetics, constructability, reasonableness, convenience and consistent stream into the administrative lifecycle of the project (Bernstein \& Jones, 2009; Cassino et al., 2014).

With the Design-Bid-Build (DBB) system, mid development alterations can be required amid development to bring the projects in line with the owner's genuine needs. DBB legally binding commitments regularly incentivize individual, instead of whole-project, optimisation that may lead to conflict between project partners (Collins et al., 2014).

Alternate sets of project case studies flaw out: In IPD, integration with the plan and development group individuals would give clarity to the conclusion client as to the real venture scope communicated within the development records. Hence, the require for proprietor asked changes may be decreased as the conclusion client would have a more total understanding of the aiming project quality and fetched earlier to the begin of development (Collins et al., 2014)

IPD is distinctive from other conveyance strategies in that it requires early and persistent collaboration of all the parties included within the project plan (Nawi et al., 2014). Eventually the objective of IPD is to "make better buildings faster for less" (Thomsen C.B, 2008).It advances the project plan within all its stages, empowering greater collaborative control and inspection when the model is completed, which itself holds all the data that supports the development (Goulding et al., 2014). Utilizing the IPD strategy with BIM in combination may be an unplanned approach to the plan and construction stages of the project (Eadie et al., 2013)

\subsection{Benefits of IPD}

Research in US construction have attempted to understand the consequences of factors including success or failure on the IPD project delivery methods along with the use of BIM (Wong et al., 2010). Project success depends on the good working relationship, respect, and trust, along with good leadership for a IPD based project system (Kent et al., 2010). IPD brings the skill of key project participants from developers, administrators,, manufacturers, contractors and fabricators to proprietors and planners prior to tender (Lee et al., 2014; Abrishami et al.,2014 ).This permits the production of a project plan that's optimized for quality, aesthetics, constructability, convenience and ensures a collaboration during the project's lifecycle (Bernstein \& Jones, 2009; Cassino et al., 2014).To attain a common objective within the project team, and to extend the efficiency and quality among the group, collaboration is required. BIM offers a number of opportunities to collaborate during the course of the project (Eastman et al., 2008).

It is difficult to implement IPD; but implementation offers many rewards, as outlined in table 1. Benefits are Shared project risk allows project participants to move beyond their conventional project role (AIA California Council, 2007).Financial incentives increase all group members' engagement, building trust within the group. (Owen et al., 2010). Greater opportunity to innovate, use new technology, and overcome silos with an emphasis on what is best for the group, rather than individuals(Wright, 2012). After approval, the client is more likely to get a building configuration that meets their requirements within their budget (Wright, 2012). Building of a solid project team and increasing working motivation and enjoyment for individual team members (Owen et al., 2010). Sharing of best practice and lessons learnt across the project participants to increase project, person and firm productivity (AIA California Council, 2007) A stronger focus on values such as public engagement or client involvement (AIA California Council, 2007). The critical analysis from the literature review is presented in a tabular format, portraited in Table 1, to understand the evolution achieved by the previous research in this area in the last decade.

\subsection{Challenges involved in implementing IPD}

IPD is widely recommended when AIA introduced the first IPD agreement in 2007 (Elghaish and Abrishami 2020). In the following years, it emerged as an innovative project delivery system with the potential to improved contracts through the integration of the supply chain.

Some impediments to BIM and IPD exist, including issues of computer platforms interoperability and the fears concerning sharing risks collaboratively - but industry pioneers were willing to work these issues through in order to make progress with this new system. The challenges that ordinarily confront IPD schemes can include (Owen et al., 2010): Increased upfront costs for the client during the approval and pre-construction phases; Strain for specialists and project participants to adjust to this new mindset; Issues forming an open and collaborative environment among the different stakeholders On initial review, it appears there are more positive than negative 
factors than cons when we consider IPD implementation, and it could be suggested that IPD would work well in a post-COVID world (Ganesh, 2020). Table 2 summarises the problems related to implementing IPD, with the main themes: Legal, Technological, Cultural, Financial, other issues (Roy et al., 2018).

\section{TABLE 1: Pool of advantages from previous studies}

\begin{tabular}{|c|c|c|c|c|c|c|c|c|c|c|c|c|c|c|c|c|}
\hline 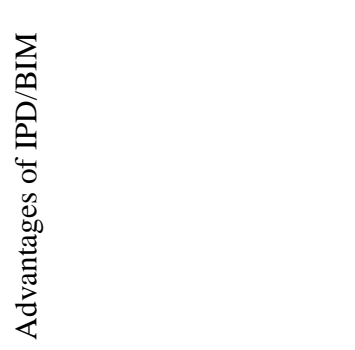 & 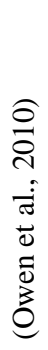 & 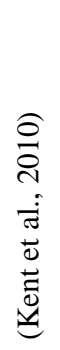 & 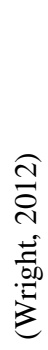 & 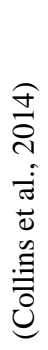 & 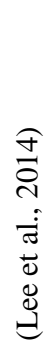 & 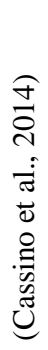 & $\begin{array}{l}\stackrel{\jmath}{\delta} \\
\text { d } \\
\dot{0} \\
\stackrel{0}{0}\end{array}$ & 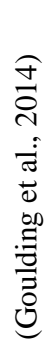 & 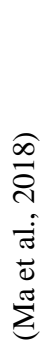 & 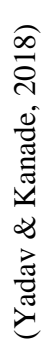 & 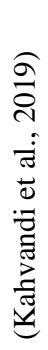 & 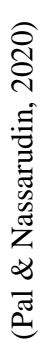 & 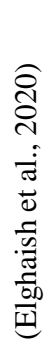 & 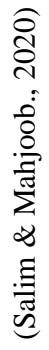 & 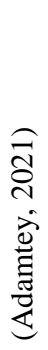 & 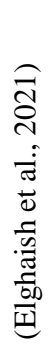 \\
\hline $\begin{array}{l}\text { Empowering the Owner \& } \\
\text { Stakeholders }\end{array}$ & & & $\sqrt{ }$ & & & & $\sqrt{ }$ & & & $\sqrt{ }$ & $\sqrt{ }$ & $\sqrt{ }$ & $\sqrt{ }$ & & $\sqrt{ }$ & $\sqrt{ }$ \\
\hline $\begin{array}{l}\text { Incentivises lower project } \\
\text { cost }\end{array}$ & & $\sqrt{ }$ & & $\sqrt{ }$ & & & & & & & & $\sqrt{ }$ & $\sqrt{ }$ & $\sqrt{ }$ & & \\
\hline $\begin{array}{l}\text { Transparent } \\
\text { process }\end{array}$ & $\sqrt{ }$ & & & & $\sqrt{ }$ & & & & & & & & & & $\sqrt{ }$ & \\
\hline $\begin{array}{l}\text { Added value: } \\
\text { Time, Quality, Reduced } \\
\text { risks }\end{array}$ & $\sqrt{ }$ & & $\sqrt{ }$ & & $\sqrt{ }$ & $\sqrt{ }$ & & & $\sqrt{ }$ & & $\sqrt{ }$ & $\sqrt{ }$ & $\sqrt{ }$ & & & \\
\hline Reduced conflict & & & & & & & $\sqrt{ }$ & & $\sqrt{ }$ & & & & & & & \\
\hline Reduced cost & $\sqrt{ }$ & & $\sqrt{ }$ & $\sqrt{ }$ & & & $\sqrt{ }$ & & $\sqrt{ }$ & & $\sqrt{ }$ & $\sqrt{ }$ & $\sqrt{ }$ & & & $\sqrt{ }$ \\
\hline Reduced timeline & & & & & & $\sqrt{ }$ & $\sqrt{ }$ & & $\sqrt{ }$ & & $\sqrt{ }$ & $\sqrt{ }$ & & & & \\
\hline $\begin{array}{l}\text { Shared ideas, goals/ } \\
\text { objectives }\end{array}$ & $\sqrt{ }$ & & & & $\sqrt{ }$ & & $\sqrt{ }$ & $\sqrt{ }$ & & $\sqrt{ }$ & $\sqrt{ }$ & & & $\sqrt{ }$ & $\sqrt{ }$ & \\
\hline Flexibility & $\sqrt{ }$ & & & & & & & & & & & $\sqrt{ }$ & & & & \\
\hline Binds teams together & & & & & $\sqrt{ }$ & $\sqrt{ }$ & $\sqrt{ }$ & $\sqrt{ }$ & & $\sqrt{ }$ & & & & & $\sqrt{ }$ & $\sqrt{ }$ \\
\hline Culture of collaboration & $\sqrt{ }$ & & $\sqrt{ }$ & $\sqrt{ }$ & & & $\sqrt{ }$ & $\sqrt{ }$ & $\sqrt{ }$ & $\sqrt{ }$ & & $\sqrt{ }$ & $\sqrt{ }$ & $\sqrt{ }$ & $\sqrt{ }$ & $\sqrt{ }$ \\
\hline Trust \& transparency & & & & & $\sqrt{ }$ & & & & & & & & $\sqrt{ }$ & $\sqrt{ }$ & & $\sqrt{ }$ \\
\hline Shared risks, rewards & & $\sqrt{ }$ & & & $\sqrt{ }$ & $\sqrt{ }$ & & & & $\sqrt{ }$ & & $\sqrt{ }$ & & $\sqrt{ }$ & $\sqrt{ }$ & $\sqrt{ }$ \\
\hline $\begin{array}{l}\text { Innovative, cost-effective } \\
\text { idea }\end{array}$ & & $\sqrt{ }$ & $\sqrt{ }$ & $\sqrt{ }$ & & & & $\sqrt{ }$ & & & $\sqrt{ }$ & $\sqrt{ }$ & & $\sqrt{ }$ & & \\
\hline $\begin{array}{l}\text { Shared } \\
\text { accountability }\end{array}$ & & & & & $\sqrt{ }$ & $\sqrt{ }$ & & & & & & $\sqrt{ }$ & & & & \\
\hline $\begin{array}{l}\text { Binds multi-parties, single } \\
\text { contract }\end{array}$ & & & $\sqrt{ }$ & & $\sqrt{ }$ & & $\sqrt{ }$ & & & $\sqrt{ }$ & & & $\sqrt{ }$ & $\sqrt{ }$ & $\sqrt{ }$ & $\sqrt{ }$ \\
\hline $\begin{array}{l}\text { Allowing decision by } \\
\text { consensus }\end{array}$ & & & & & & & & & & & $\sqrt{ }$ & & & $\sqrt{ }$ & $\sqrt{ }$ & \\
\hline $\begin{array}{l}\text { Assign roles to people best } \\
\text { suited for the job }\end{array}$ & & & & & & & & $\sqrt{ }$ & & $\sqrt{ }$ & & & & & & \\
\hline Relational contracts & & & & & & & & & & & & $\sqrt{ }$ & $\sqrt{ }$ & & & $\sqrt{ }$ \\
\hline Equal representation & & & & & & & & & & $\sqrt{ }$ & & $\sqrt{ }$ & & & & \\
\hline Precision estimate & & & & $\sqrt{ }$ & & & $\sqrt{ }$ & & $\sqrt{ }$ & & & $\sqrt{ }$ & & & & $\sqrt{ }$ \\
\hline Value relation abilities & $\sqrt{ }$ & & & & & & & & & $\sqrt{ }$ & & & & & & $\sqrt{ }$ \\
\hline
\end{tabular}


TABLE 2: Drawbacks of IPD from the literature.

\begin{tabular}{|c|c|c|c|c|c|c|c|c|c|c|c|c|}
\hline Challenges in IPD & 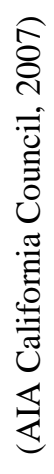 & 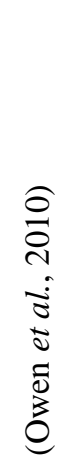 & 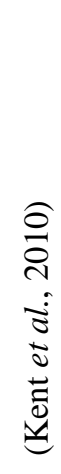 & 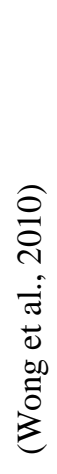 & 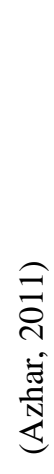 & 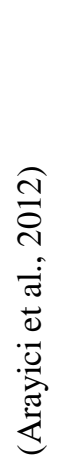 & 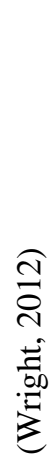 & 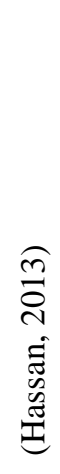 & 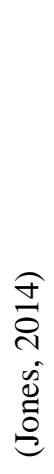 & 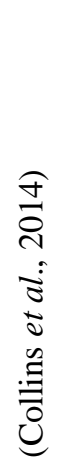 & 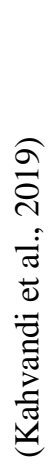 & 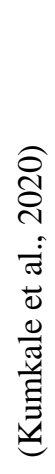 \\
\hline $\begin{array}{l}\text { Incorporation of } \\
\text { Data and Knowledge } \\
\text { management system }\end{array}$ & $\sqrt{ }$ & $\sqrt{ }$ & & & & $\sqrt{ }$ & $\sqrt{ }$ & $\sqrt{ }$ & & & & $\sqrt{ }$ \\
\hline $\begin{array}{l}\text { Exaggerated planning } \\
\text { cross functional roles of } \\
\text { Owners, Stakeholders, } \\
\text { contractors }\end{array}$ & $\sqrt{ }$ & $\sqrt{ }$ & & $\sqrt{ }$ & & & & $\sqrt{ }$ & & $\sqrt{ }$ & $\sqrt{ }$ & \\
\hline $\begin{array}{l}\text { Slower decision process, } \\
\text { delayed feedback }\end{array}$ & & $\sqrt{ }$ & $\sqrt{ }$ & & & $\sqrt{ }$ & & & & & & $\sqrt{ }$ \\
\hline $\begin{array}{l}\text { Lack of expertise on } \\
\text { technology }(\mathrm{BIM} / \mathrm{CDE})\end{array}$ & & & $\sqrt{ }$ & $\sqrt{ }$ & $\sqrt{ }$ & & & $\sqrt{ }$ & $\sqrt{ }$ & & $\sqrt{ }$ & \\
\hline $\begin{array}{l}\text { Involvement of key } \\
\text { project associated. } \\
\text { delayed/inappropriate } \\
\text { timing }\end{array}$ & $\sqrt{ }$ & $\sqrt{ }$ & & & & $\sqrt{ }$ & & & & $\sqrt{ }$ & & $\sqrt{ }$ \\
\hline $\begin{array}{l}\text { Issue over BIM standards } \\
\text { and specifications }\end{array}$ & & & $\sqrt{ }$ & $\sqrt{ }$ & & $\sqrt{ }$ & & $\sqrt{ }$ & $\sqrt{ }$ & & $\sqrt{ }$ & \\
\hline $\begin{array}{l}\text { Legal hassle for updated } \\
\text { framework }\end{array}$ & $\sqrt{ }$ & & $\sqrt{ }$ & & $\sqrt{ }$ & & & & & $\sqrt{ }$ & $\sqrt{ }$ & \\
\hline $\begin{array}{l}\text { Shorter schemes: Time } \\
\text { issues implementing IPD }\end{array}$ & $\sqrt{ }$ & & & $\sqrt{ }$ & & & & & & & & $\sqrt{ }$ \\
\hline $\begin{array}{l}\text { Third party } \\
\text { untrustworthy claims }\end{array}$ & & & & $\sqrt{ }$ & $\sqrt{ }$ & & $\sqrt{ }$ & & & & $\sqrt{ }$ & \\
\hline $\begin{array}{l}\text { Lack } \\
\text { of insurance coverage }\end{array}$ & & & $\sqrt{ }$ & & & & & & & & & $\sqrt{ }$ \\
\hline $\begin{array}{l}\text { Reward/losses structured } \\
\text { issues }\end{array}$ & & & & $\sqrt{ }$ & & $\sqrt{ }$ & & $\sqrt{ }$ & & & & \\
\hline Profit sharing pool issue & & & & & $\sqrt{ }$ & & & & $\sqrt{ }$ & & $\sqrt{ }$ & \\
\hline $\begin{array}{l}\text { Accounting differences } \\
\text { among owners } \\
\text { /stakeholders }\end{array}$ & $\sqrt{ }$ & & $\sqrt{ }$ & & & & $\sqrt{ }$ & & & $\sqrt{ }$ & $\sqrt{ }$ & \\
\hline $\begin{array}{l}\text { Software training and } \\
\text { skill sets not upgraded }\end{array}$ & & $\sqrt{ }$ & $\sqrt{ }$ & & $\sqrt{ }$ & $\sqrt{ }$ & & & $\sqrt{ }$ & & & \\
\hline Joint Ownerships issue & $\sqrt{ }$ & & & $\sqrt{ }$ & & & $\sqrt{ }$ & & & $\sqrt{ }$ & $\sqrt{ }$ & $\sqrt{ }$ \\
\hline $\begin{array}{l}\text { Inexperience in } \\
\text { handling IPD projects }\end{array}$ & $\sqrt{ }$ & $\sqrt{ }$ & $\sqrt{ }$ & $\sqrt{ }$ & $\sqrt{ }$ & & & $\sqrt{ }$ & $\sqrt{ }$ & $\sqrt{ }$ & $\sqrt{ }$ & \\
\hline $\begin{array}{l}\text { BIM costs issues/ } \\
\text { ownership hassle }\end{array}$ & & & & $\sqrt{ }$ & $\sqrt{ }$ & $\sqrt{ }$ & & & $\sqrt{ }$ & & & $\sqrt{ }$ \\
\hline Fear of change & & $\sqrt{ }$ & & & $\sqrt{ }$ & & $\sqrt{ }$ & $\sqrt{ }$ & & $\sqrt{ }$ & & $\sqrt{ }$ \\
\hline
\end{tabular}




\section{RESEARCH GAP AND MOTIVATION}

Research related to IPD and BIM has been well documented in recent research (Eastman et al., 2008; PishdadBozorgi et al., 2018) . However, there are limited documents available which examine the advantages and the disadvantages of IPD and BIM implementation within the UK consulting sector.

To date, research on the use of both BIM \& IPD, has not fully explored their implementation in the construction consulting sector - this opens a window to further studies on these topics individually as well as in combination (Yadav \& Kanade, 2018), (Jin et al., 2020). Using an IPD framework to resolve different issues of conventional contracting frameworks is important and timely (Nawi et al., 2014). Furthermore, establishing and classifying the limitations in implementation of IPD and BIM is the first step in being able to resolve them (Jobidon et al., 2021).

In the UK consulting sector, progress has been made in terms of using BIM and IPD after the announcement of the UK Government Construction Strategy (GCS):2016-2020 ("Building Information Modelling," 2016). Nevertheless, there is little research in terms of utilizations of these strategies by the consulting sector, and how the consulting sector is delivering the UK government's strategy of using BIM and IPD. . Merely any research paper is available on any online portal providing any information related to the consulting sectors. It is therefore an opportune time to explore whether there are barriers and benefits to be exploited by moving towards implementing BIM with IPD methods development within the UK construction consulting sector,

\section{RESEARCH METHOD}

A qualitative approach has been adopted. Qualitative methods allow the researcher to explore the implied experience of individuals which is often exceptionally difficult to investigate (Yin, 2003) Interview questions were developed following analysis of previous research. The one-to-one interviews were conducted using a video meeting platform. Using a semi-structured method, it was important to develop core questions which would enable the interviewer to fully explore the topic. The interview questions were provided to the participant in advance of the interview. Each interview was then transcribed and anonymized. This data used in this research study was conducted between June and August 2021. Theeight interviewee participants were from the UK consulting sector. Table 3 shows the interviewee job background and their experience. Interviews typically lasted between for 40-50 minutes.

TABLE 3: List of Interviewee by work sector, work role, experience in the consulting/construction field within the $U K$.

\begin{tabular}{|l|l|l|l|}
\hline No. & Work Sectors & Job Title/ Work area & $\begin{array}{l}\text { Overall Experience/ } \\
\text { BIM/IPD experience }\end{array}$ \\
\hline B1. & $\begin{array}{l}\text { Consulting \& } \\
\text { Construction }\end{array}$ & $\begin{array}{l}\text { Technical director / } \\
\text { Senior structural engineer }\end{array}$ & $\begin{array}{l}\text { 23 years. / } \\
\text { 5 years. }\end{array}$ \\
\hline B2. & $\begin{array}{l}\text { Consulting \& } \\
\text { Construction }\end{array}$ & $\begin{array}{l}\text { Discipline lead / } \\
\text { Principle highway manager }\end{array}$ & $\begin{array}{l}\text { 16 years. / } \\
7 \text { years. }\end{array}$ \\
\hline B3. & Consulting & $\begin{array}{l}\text { BIM manager / } \\
\text { Senior BIM expert }\end{array}$ & $\begin{array}{l}\text { 23 years. / } \\
6 \text { years. }\end{array}$ \\
\hline B4. & Consulting & $\begin{array}{l}\text { Senior project manager / } \\
\text { Principle highway manager }\end{array}$ & $\begin{array}{l}\text { 18 years. / } \\
10 \text { years. }\end{array}$ \\
\hline B5. & Consulting & $\begin{array}{l}\text { Discipline lead / } \\
\text { Senior structural engineer }\end{array}$ & $\begin{array}{l}10 \text { years. / } \\
\text { 3 years. }\end{array}$ \\
\hline B6. & $\begin{array}{l}\text { Consulting \& } \\
\text { Construction }\end{array}$ & $\begin{array}{l}\text { Senior engineer / } \\
\text { Highway design engineer }\end{array}$ & $\begin{array}{l}\text { 10 years. / } \\
7 \text { years. }\end{array}$ \\
\hline B7. & Consulting & $\begin{array}{l}\text { Project manager/ } \\
\text { Lead drainage engineer }\end{array}$ & $\begin{array}{l}\text { 10 years. / } \\
6 \text { years. }\end{array}$ \\
\hline B8. & Consulting & $\begin{array}{l}\text { Senior civil engineer/ } \\
\text { Highway design engineer } \\
\text { 6years. / }\end{array}$ \\
\hline
\end{tabular}


Inductive thematic analysis was used. By employing an inductive method, findings and topics are connected to the qualitative information. NVivo 12 software was utilized to code the transcripts and aid thematic analysis. Use of CAD helps to make the analysis more comprehensive and robust.

Figure 1 shows the coding of the 'Themes' that were developed, based on four aspects of the topic in question.

1. Hurdles in IPD and BIM

2. Best possible connector BIM \& IPD

3. Improvements for future path

4. Future of BIM \& IPD in the UK

\begin{tabular}{|c|c|}
\hline Coding & Percentage coverage \\
\hline Codes \IHURDLES IN BIM IPD & $31.47 \%$ \\
\hline Codes\\
FUTURE OF BIM IPD IN UK & $23.80 \%$ \\
\hline CodeS \VIMPROVEMENT FOR FUTURE PATH & $23.43 \%$ \\
\hline Codes\\
BEST POSSIBLE CONNECTOR BIM IPD & $19.04 \%$ \\
\hline Codes \\
FUTURE OF BIM IPD IN UK\Factors affecting BIM implementation & $14.90 \%$ \\
\hline Codes\VIMPROVEMENT FOR FUTURE PATH Collaboration improving factors due to BIM on IPD & $12.44 \%$ \\
\hline Codes $\backslash \backslash B E S T$ POSSIBLE CONNECTOR BIM IPD\Motivation for IPD \& BIM in firm & $8.33 \%$ \\
\hline Codes IVIMPROVEMENT FOR FUTURE PATHIOperation, Maintainance, FM affects by IPD & $8.06 \%$ \\
\hline Codes $\backslash \backslash B E S T$ POSSIBLE CONNECTOR BIM IPD\BIM helping to manage risks & $7.75 \%$ \\
\hline Codes\\
FUTURE OF BIM IPD IN UK\Future of BIM \& IPD & $7.60 \%$ \\
\hline Codes \\
HURDLES IN BIM IPD \Improvement required in multi-party Contracts & $6.00 \%$ \\
\hline Codes\\
HURDLES IN BIM IPD ISecurity concern for BIM \& IPD & $5.08 \%$ \\
\hline Codes $\backslash$ HURDLES IN BIM IPD \BIM implemntation checks in the organiaztion & $4.38 \%$ \\
\hline Codes\\
HURDLES IN BIM IPD \BIM standards measured in orginisation & $3.18 \%$ \\
\hline Codes \\
Role \& Responsibility & $3.05 \%$ \\
\hline Codes $\backslash \backslash B E S T$ POSSIBLE CONNECTOR BIM IPDIRFI's mitigation, Security, sharing datas & $2.44 \%$ \\
\hline Codes $\backslash \backslash B E S T$ POSSIBLE CONNECTOR BIM IPD\Profit sharing- all party & $1.68 \%$ \\
\hline Codes \IExperience BIM-IPD & $0.48 \%$ \\
\hline
\end{tabular}

FIG. 1 Themes coded following analysis.

\section{RESULTS}

\subsection{Scope of BIM and IPD within the UK}

The codes generated during the analysis indicate the barriers to IPD and BIM integration that exist in the UK consulting sector. Interviewees were asked to suggest possible solutions for these barriers. Figure 2 shows barriers and suggested solutions and FIG. 3, provides a chart showing the analysis coding hierarchy Four main themes were developed within this research study.

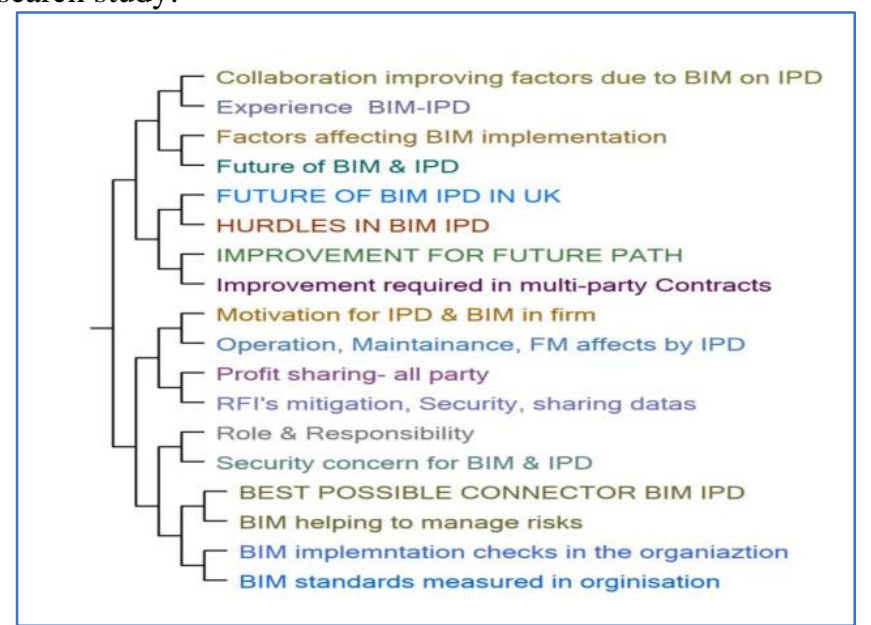

FIG. 2 Cluster analysis from the codes in the NVivo 12 software 


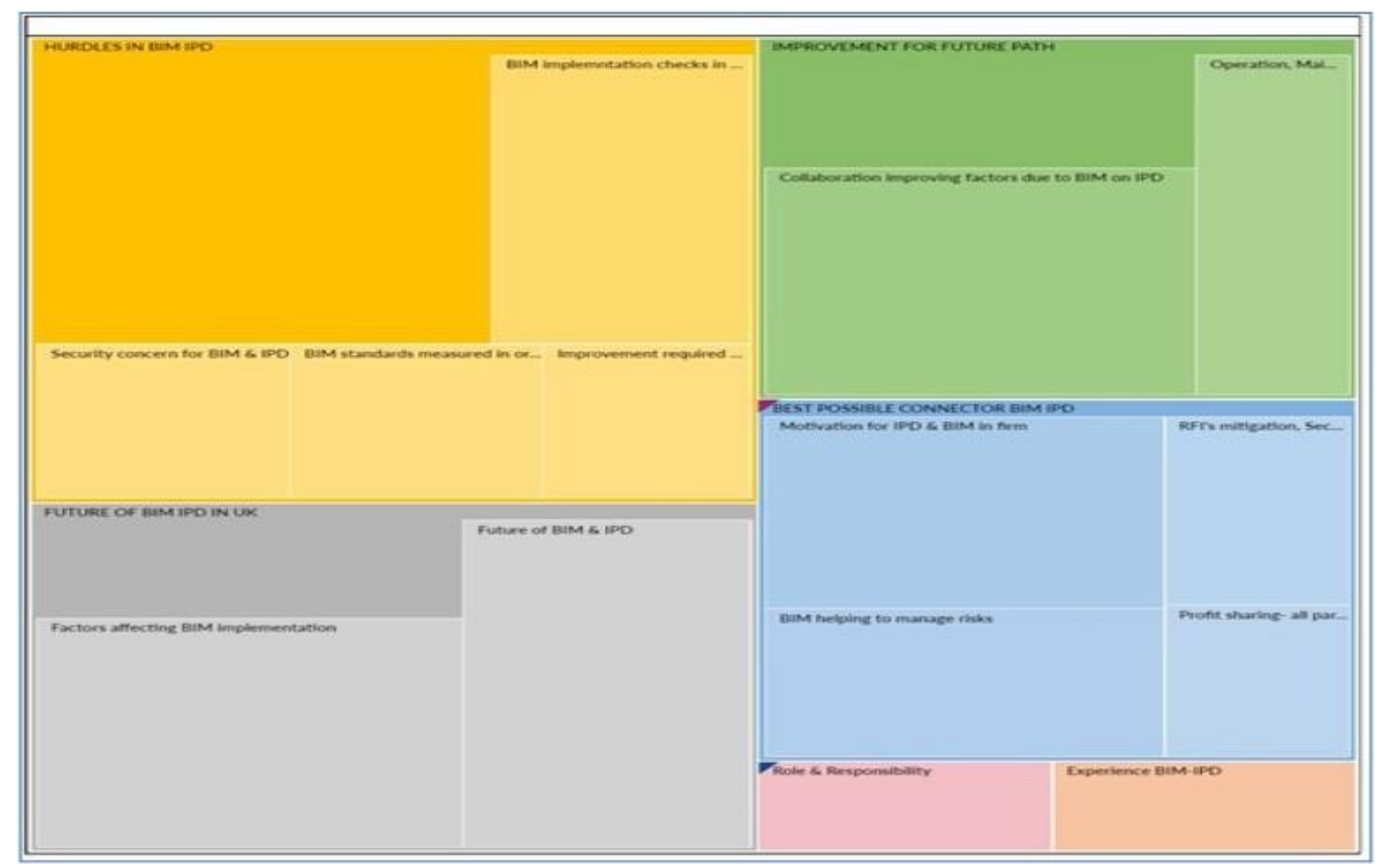

FIG. 3 Thematic hierarchy chart using NVivo 12 software, from the analysis

\subsection{Theme 1: Best connector for IPD is BIM}

This theme indicates that the interviewees consider BIM implementation to be the best connector for IPD schemes for the consulting sectors in the UK.

'BIM offers improved coordination and collaboration between the design teams and the construction site teams' (Interviewee B1, B4, B5, B6, B7, B8). This is accepted by most interviewees, providing a clear indication that BIM is important for IPD projects. Implementation of BIM on major projects proved to be time and cost-efficient whist maintaining quality standards. Project teams can work on the design model around the clock and around the globe, on IPD projects, which eventually helps in delivering the projects in lesser time than anticipated (Interviewee B2, B4, B6, B8). The term 'connector' is used to describe the aspects of BIM where IPD projects are being designed and modelled in different part of the world. The design model can be developed by design teams remotely working on these $3 \mathrm{D}$ models. This is the fertile consequence of IPD projects using BIM as the main collaborative and coordinating tool.

Use of BIM reduces the time and cost previously required for printing hard copies of drawings (Interviewee B2). This suggested a reduced 'carbon footprint' reduction for multi-national consulting firms around the globe, for adopting BIM within the IPD projects. Implementing BIM within IPD schemes helps reduced to the overall cost, time, and make more sustainable project outcomes from the construction works in projects (Interviewee B1, B2, B5, B6, B7).

\section{Common Data Environment (CDE) \& Information sharing:}

BIM tools facilitate in quality control optimization throughout the project lifecycle. Design information is managed efficiently and the 'risks of loss' in project information are reduced (Interviewee B2, B3, B5, B7, B8). Information and visualisation is provided to the clients - this helps reduce changes and alleviates cost on sites (Interviewee B2, B3, B6, B7). The Common data environment (CDE) is an efficient and seamless way to work on with BIM environment, (Interviewee B3).

BIM permits early identification of clashes on sites, early identification of design problems and their resolution prior to completion of detailed design. It allows for better management of interdisciplinary tasks (Interviewee B4). 
BIM improves the development of a design and enables smoother construction onsite (if used correctly) (Interviewee B5). Interviewee B7 describes the idea of collaboratively working on an inter-disciplinary basis seamlessly on site, with proper dealing of information - without losing track, and managing data for asset management for maintenance projects.

Interviewee B7 describes how his organisation is 'hoping to move from paper records to digital cloud hosted information'. The awareness of providing accurate inter-disciplinary information from correct data sources with the confidence to client queries enabled within the BIM work environment, aligns profoundly with the IPD projects.

\subsection{Theme 2: Drawbacks of the IPD and BIM connector.}

A primary drawback to using BIM to connect parties under an IDP arrangement is the delay in developing coordinated 3D models - this can be due to inexperienced BIM information authors, or poor team knowledge of integrating IPD and BIM. Lack of responsiveness on BIM issues throughout project delivery partners, stakeholders, and supply chains, can result in a missed opportunity between design and construction teams (Interviewee B1). The quality of deliverables can be impacted due to lack of knowledge of the BIM process, impacting overall project cost (Interviewee B2). IPD projects can provide for multi-cultural project teams working under one umbrella, but poor BIM implementation can impact the delivery program and quality standards, ultimately leading to an escalation in project cost.

Interviewee 3 remarked about the risk of moving teams to work on project specific, high-cost BIM software, impacting an entire organisation. There is a perception amongst some that investing in BIM software and training throughout an organisation can be a costly procedure (Interviewee B4). Adopting an entirely new way of dealing with projects, differing from traditional project delivery, providing training and learning the new processes associated with an innovative project delivery with IPD norms and BIM guidelines, can cause additional project costs to consulting sectors in the UK.

Setting up of the $\mathrm{CDE}$ for any project must be agreed with the project teams, and client. According to interviewee $\mathrm{B} 4$, the process of granting access to the $\mathrm{CDE}$, and the process of auditing information provided for working in cross-functional design teams can impact project delivery.

Successful IPD and BIM implementation requires a willingness to change behavioral patterns and adopting new framework norms. Culture change is required to make sure that appropriate project strategies are in place and that they are being implemented for the development of BIM and IPD coupling. Interviewees B1, B3, B5, B6, B7 \& B8 accept that the difficulties engendering behavior and cultural change in the mindset of individuals is the main cause of hindrance in the implementation of BIM integrated with IPD.

Unsuitable contractual agreements for IPD and BIM adoption correspondingly damage implementation in any organisation (Interviewees B1, B3, B4, B5, B7). Appropriate contracts are the key to initiate good relationships among stakeholders, owners and other project parties.

\subsection{Theme 3: Overcoming the drawbacks of IPD \& BIM implementation}

In this digital age and in the Covid19 scenario, organisations have embraced the digital meeting environment and shown that collaboration through these methods can be successful. BIM implementation agreed in the contract stage improves collaboration between owners, design teams, stakeholders, and contractors according to interviewees B1, B2, B3, B4 andB5.With implementation of BIM in IPD schemes, behavior, technology and process require a change for every part of the supply chain, to move to the higher level of collaboration (Interviewee B3, B6, B7).

BIM and IPD enables all project associated teams to coordinate and work together towards a common goal (Interviewee B3, B6, B7). High performance teams can be created by the continuous learning process. The 'lessons learnt' from past projects can be reviewed at start of the new project. One of these lessons cited by an interviewee is that organisations need to ensure regular training on the software and tools relevant for BIM for a particular project.

Mangers must ensure project team participants understand their individual roles and responsibilities within the BIM execution plan (BEP) (Interviewee B3, B7, B8). BIM with the CDE and other technology allows a smoother process for handover and review and information between various disciplines, if adopted correctly. 


\subsection{Theme 4: Future of BIM \& IPD in the UK}

The interviewees agreed to the suggestion that BIM is the future - combined with IPD this can speed tha 'digital transformation' that the UK, is currently going through. The implementation of BIM has allowed for a greater involvement of a wider range of disciplines compared to the traditional design team, and also gains input from the client and contractor. This has allowed for greater value to be added to, and better validation of, designs before construction. If some of the hurdles relating to the technology and the processes can be overcome, then BIM and IPD will start to become a standard approach, rather than just used for large schemes (Interviewee B6).

\section{DISCUSSION, SIGNIFICANCE AND LIMITATION}

The literature reviews indicates that there are sustainable benefits from the infrastructure projects that adopt a BIM based approach. The benefits include that delivery effort required is cut down by a factor to one-to-five (Kumar et al., 2017).

The qualitative analysis undertaken in this study provides an in-depth exploration of the combination of BIM and IPD projects in the UK infrastructure sector. All interviewees agree that there is an evolving picture with respect to adoption of 'digital twins' and digital transformation around the globe and the UK. The analysis indicates that using BIM to aid IPD schemes is beneficial, adds value to a project, and acts as a good 'connector' for the project participants amongst the consulting sectors.

The barriers for the implementation of BIM with IPD schemes are discussed in the section 4, the main barriers can be categorised thus:

1. Difficulty with cultural behavior changes / adopting a new mentality

2. Software cost

3. Lack of expertise of BIM or IPD

4. Contractual agreement complications,

5. A suitable CDE setup,

According to the qualitative analysis outcomes the barriers to BIM implementations on IPD projects can be overcome with measures discussed in section 4 , which can be summarised as:

- Contractual agreements detailing the required collaboration with clients, other stakeholders, and contractors, consultants, collaborative active participation at an early stage of involvement in the project.

- Use of 'Lessons learnt' from prior project experience, with appropriate utilization for the learning curve and passing on knowledge.

- Understanding the BEP, CDE and project specified roles and responsibilities. Bonding, collaboration, and trust building among project members and inter-disciplinary teams.

A cohesive teamwork is characterized by good team chemistry, commitment, and ease of communication. Project delivery methods that include transparency with open-book contracts and qualification-based choice of the builder bring about more cohesive groups and a lower than average project cost growth (Franz et al., 2017).

The qualitative analysis suggests that with the 'digital twin' will take BIM adoption for IPD collaboration to the next level in the future. As pointed out by Interviewee 7, "on a professional social media platform, people associated with BIM and IPD are nowadays continuously talking about BIM and 3D laser scanning. Creating digital twins of project assets, which certainly is a more efficient way of collaboration and managing data for maintenance projects. Collection of data and sharing with the project team, the using of $3 D$ point clouds are very useful on design and construction projects going forward."

There is a contradictory statement from one of the interviewees, B4, who fears that the journey to of IPD and BIM adoption in the future may not be smooth: "...I 'think we should strive for this though although being on the journey at times does feel painful." 


\section{CONCLUSION}

This research has explored the benefits and challenges of implementing IPD and BIM from a UK consultant perspective. Eight interviewees were conducted with experienced consultants all of whom were involved in large infrastructure projects in the UK.

The involvement of contractors at an early stage of any project should be encouraged, providing healthier relations among all the project participants. This is a key requisite of IPD delivery. The BEP is key to understand the detailed contractual aspect of any BIM projects with in-depth deliverable lists. Poor BEPs have the potential to disrupt the relationship among the project stakeholders, owners, contractors or consultants. Implementation of BIM could be encouraged at early stage of IPD contract agreement, which apparently improves collaboration between all parties.

Appreciating individual project specific roles and the responsibilities among the team members must be discussed prior to the project kickoff, and the project manager should ensure that these are specified among cross team members and are widely accepted. A continuous learning process could create high performance project teams. Lessons learnt from previous projects should be treated as important guidance for team members involved in crossfunctional projects. The cultural inclusion aspect should be considered amongst the integrated teams. IPD requires multi-party team collaboration, where cultural barriers among team-members could eventually affect the overall project relationships, information flow and thus hamper the project outcome. Culturally inclusive team building should be promoted among the consulting workforce employed on IPD projects.

Organizations alike BRE, must mandate the usage of collaborative workflow along with the use BEP, IPD workflow, CDE, BIM tools, and MIDPs for future projects. As this study has discussed, there is a lack of in-depth expertise in the field of BIM and IPD in industry, a gap in knowledge which this paper aimed to address. Detailed training is required for Industry participants in the integration and adoption of BIM and IPD for optimal project delivery.

This study has adopted a qualitative approach and has been constrained in terms of timeframe and number of project participants. Future studies could examine this issue with a greater number of interview participants. It would be of interest to compare approaches with BIM and IPD adoption in the UK to those used in other jurisdictions, to explore whether the barriers and mitigations found in this study are unique to the UK, or more geographically widespread. This paper recommend that the UK government must encourage the use of BIM software in IPD projects within the infrastructure industry. With proper standardization of BIM workflows to suit IPD frameworks, the benefits of this approach should be promoted throughout the industry.

\section{REFERENCES}

Abrishami, S., Goulding, J., Rahimian, F. P., Ganah, A. \& Sawhney, A. 2014. G-BIM framework and development process for integrated AEC design automation. Procedia Engineering, 85, 10-17.

Adamtey, S. A. (2021). A Case Study Performance Analysis of Design-Build and Integrated Project Delivery Methods. International Journal of Construction Education and Research, 17(1), 68-84. https://doi.org/10.1080/15578771.2019.1696903

AIA California Council. (2007). Integrated Project Delivery: A Guide California Council National.

Arayici, Y., Egbu, C., \& Coates, P. (2012). Building Information Modelling (BIM) Implementation and Remote Construction Projects: Issues, Challenges, and Critiques. Journal of Information Technology in Construction (ITcon) (Vol. 17). http://www.itcon.org/2012/5

Autodesk Construction Cloud. (2020). Top Benefits of BIM for Contractors. Autodesk Construction Cloud.

Azhar, S. (2011). Building Information Modeling (BIM): Trends, Benefits, Risks, and Challenges for the AEC Industry (Vol. 11, Issue 3).

Bernstein, H. M., \& Jones, S. A. (2009). Modeling (BIM) Building Information Transforming Design and Construction to Achieve Greater Industry Productivity.

Bilge, E. C., \& Yaman, H. (2021). Information management roles in real estate development lifecycle: literature review on BIM and IPD framework. In Construction Innovation. https://doi.org/10.1108/CI-04-2019-0036 
Building Information Modelling. (2016). HM Goverment: Building Information Modelling. http://www.bimtaskgroup.org/wp-

Carvalho, J. P., Bragança, L., \& Mateus, R. (2020). A systematic review of the role of BIM in building sustainability assessment methods. Applied Sciences (Switzerland), 10(13). https://doi.org/10.3390/app10134444

Cassino, K. E., Bernstein, H. M., Asce, F., Ap, L., Russo, M. A., Advisor, A. E., Jones, S. A., Laquidara-Carr, D., Manager, W. T., Operations, C., Ramos, J., Director, A., Lorenz, A., \& Yamada, T. (2014). Smart Market Report McGraw Hill Construction The Business Value of BIM for Construction in Major Global Markets: How Contractors Around the World Are Driving Innovation With Building Information Modelling Smart Market Report Executive Editor. www.construction.com

Collins, W., Parrish, K., \& Webb, D. E. (2014). The Need for Integrated Project Delivery in the Public Sector.

Doumbouya, L., Gao, G., \& Guan, C. (2016). Adoption of the Building Information Modeling (BIM) for Construction Project Effectiveness: The Review of BIM Benefits. American Journal of Civil Engineering and Architecture, 4(3), 74-79. https://doi.org/10.12691/ajcea-4-3-1

Eadie, R., Browne, M., Odeyinka, H., McKeown, C., \& McNiff, S. (2013). BIM implementation throughout the UK construction project lifecycle: An analysis. Automation in Construction, 36, 145-151. https://doi.org/10.1016/J.AUTCON.2013.09.001

Eastman, C., Teicholz, P., Sacks, R., \& Liston, K. (2008). BIM Handbook Contents. BIM Handbook: A Guide to Building Information Modeling for Owners, Managers, Designers, Engineers and Contractors.

Elghaish, F., \& Abrishami, S. (2020). Developing a framework to revolutionise the 4D BIM process: IPD-based solution. Construction Innovation, 20(3), 401-420. https://doi.org/10.1108/CI-11-2019-0127

Elghaish, F., \& Abrishami, S. (2021). A centralised cost management system: exploiting EVM and ABC within IPD. Engineering, Construction and Architectural Management, 28(2). https://doi.org/10.1108/ECAM11-2019-0623

Elghaish, F., Hosseini, M. R., Talebi, S., Abrishami, S., Martek, I., \& Kagioglou, M. (2020). Factors driving success of cost management practices in integrated project delivery (IPD). Sustainability (Switzerland), 12(22). https://doi.org/10.3390/su12229539

Fischer, M., Khanzode, A., Reed, D. P., \& Ashcraft, H. W. (2017). Integrating project delivery.

Forbes, L. H., \& Ahmed, S. M. (2010). Modern construction: Lean project delivery and integrated practices. In Modern Construction: Lean Project Delivery and Integrated Practices. CRC Press. https://doi.org/10.1201/b10260

Franz, B., Leicht, R., Molenaar, K., \& Messner, J. (2016). Impact of Team Integration and Group Cohesion on Project Delivery Performance. Journal of Construction Engineering and Management, 143(1), 04016088. https://doi.org/10.1061/(ASCE)CO.1943-7862.0001219

Franz, B., Leicht, R., Molenaar, K., \& Messner, J. (2017). Impact of Team Integration and Group Cohesion on Project Delivery Performance. Journal of Construction Engineering and Management, 143(1), 04016088. https://doi.org/10.1061/(ASCE)CO.1943-7862.0001219

Ganesh, ramya. (n.d.). OVERCOMING THE IMPACTS OF COVID-19 OUTBREAK USING VALUE INTEGRATED PROJECT DELIVERY MODEL. Journal of Seybold Report . Retrieved September 11, 2021, from https://www.academia.edu/43971478/OVERCOMING_THE_IMPACTS_OF_COVID_19_OUTBREAK _USING_VALUE_INTEGRATED_PROJECT_DELIVERY_MODEL

Goulding, J. S., Rahimian, F. P., \& Wang, X. (2014). Virtual reality-based cloud BIM platform for integrated AEC projects. Journal of Information Technology in Construction, 19.

Hassan Ibrahim, N. (2013). Reviewing the evidence: USE of digital collaboration technologies in major building and infrastructure projects. Journal of Information Technology in Construction, 18.

Jin, J., Hwang, K. E., \& Kim, I. (2020). A study on the constructivism learning method for BIM/IPD collaboration education. Applied Sciences (Switzerland), 10(15). https://doi.org/10.3390/app10155169 
Jobidon, G., Lemieux, P., \& Beauregard, R. (2021). Building Information Modeling in Quebec's Procurement for Public Infrastructure: A Case for Integrated Project Delivery. Laws, 10(2). https://doi.org/10.3390/laws10020043

Jones, B. (2014). Integrated Project Delivery (IPD) for Maximizing Design and Construction Considerations Regarding Sustainability. $\quad$ Procedia Engineering, https://doi.org/10.1016/j.proeng.2014.12.214

Kahvandi, Z., Saghatforoush, E., ZareRavasan, A., \& Preece, C. (2019). Integrated Project Delivery Implementation Challenges in the Construction Industry. Civil Engineering Journal, 5(8), 1672-1683. https://doi.org/10.28991/cej-2019-03091362

Kent, D. C., Asce, S. M., Becerik-Gerber, B., \& Asce, A. M. (2010). Understanding Construction Industry Experience and Attitudes toward Integrated Project Delivery. JCEM ASCE, 136(8), 815-825. https://doi.org/10.1061/ASCECO.1943-7862.0000188

Kumkale Açıkgöz, E., \& Çetin, M. (2020). An In-Depth Inquiry on the Drawbacks of BIM Implementation. In Communications in Computer and Information Science: Vol. 1188 CCIS (pp. 15-27). https://doi.org/10.1007/978-3-030-42852-5_2

Lee, H. W., Anderson, S. M., Kim, Y.-W., \& Ballard, G. (2014). Advancing Impact of Education, Training, and Professional Experience on Integrated Project Delivery. Practice Periodical on Structural Design and Construction, 19(1), 8-14. https://doi.org/10.1061/(ASCE)SC.1943-5576.0000190

Ma, Z., Zhang, D., \& Li, J. (2018). A dedicated collaboration platform for Integrated Project Delivery. Automation in Construction, 86, 199-209. https://doi.org/10.1016/j.autcon.2017.10.024

Mertens, D. (2010). Divergence and mixed methods. Article in Journal of Mixed Methods Research, 4(1), 3-5. https://doi.org/10.1177/1558689809358406

Nawi, M. N. M., Haron, A. T., Hamid, Z. A., Kamar, K. A. M., \& Baharuddin, Y. (2014). Improving integrated practice through Building Information Modeling-Integrated Project Delivery (BIM-IPD) for Malaysian Industrialised Building System (IBS) construction projects. Malaysian Construction Research Journal, 15(2).

Omoregie, A., \& Turnbull, D. E. (2016a). Highway infrastructure and building information modelling in UK. Proceedings of the Institution of Civil Engineers: Municipal Engineer, 169(4), 220-232. https://doi.org/10.1680/jmuen.15.00020

Omoregie, A., \& Turnbull, D. E. (2016b). Highway infrastructure and building information modelling in UK. Proceedings of the Institution of Civil Engineers: Municipal Engineer, 169(4), 220-232. https://doi.org/10.1680/jmuen.15.00020

Owen, R., Amor, R., Palmer, M., Dickinson, J., Tatum, C. B., Kazi, A. S., Prins, M., Kiviniemi, A., \& East, B. (2010). Challenges for Integrated Design and Delivery Solutions. Architectural Engineering and Design Management, 6(4), 232-240. https://doi.org/10.3763/aedm.2010.IDDS1

Pal, A., \& Nassarudin, A. (2020). Integrated project delivery adoption framework for construction projects in India. IGLC 28 - 28th Annual Conference of the International Group for Lean Construction 2020. https://doi.org/10.24928/2020/0018

Pishdad-Bozorgi, P., Gao, X., Eastman, C., \& Self, A. P. (2018). Planning and developing facility managementenabled building information model (FM-enabled BIM). Automation in Construction, 87. https://doi.org/10.1016/j.autcon.2017.12.004

Roy, D., Malsane, S., \& Kumar Samanta, P. (2018). Identification of Critical Challenges for Adoption of Integrated Project Delivery(IPD) A study on 4D BIM adoptability and usability View project Project Management and Contractual Issues in Heritage Conservation in India View project. www.leanconstructionjournal.org

Salim, M. S., \& Mahjoob, A. M. R. (2020). Integrated project delivery (IPD) method with BIM to improve the project performance: a case study in the Republic of Iraq. Asian Journal of Civil Engineering, 21(6), 947957. https://doi.org/10.1007/s42107-020-00251-1 
Salim, M. S., \& Raoof Mahjoob, A. M. (2020). Achieving the Benefits and Requirements of Integrated Project Delivery Method Using BIM. IOP Conference Series: Materials Science and Engineering, 901(1). https://doi.org/10.1088/1757-899X/901/1/012033

Sheikhkhoshkar, M., Pour Rahimian, F., Kaveh, M. H., Hosseini, M. R., \& Edwards, D. J. (2019). Automated planning of concrete joint layouts with 4D-BIM. Automation in Construction, 107. https://doi.org/10.1016/j.autcon.2019.102943

Thomsen C.B. (2008). C. Thomsen, “Program Management Version 2.0," Construction Management Association of America, 2008. - References - Scientific Research Publishing. CMAA. https://www.cmaanet.org/bookstore/book/program-management-20

Wong, A. K. D., Wong, F. K. W., \& Nadeem, A. (2010). Attributes of building information modelling implementations in various countries. Architectural Engineering and Design Management, 6(SPECIAL ISSUE), 288-302. https://doi.org/10.3763/AEDM.2010.IDDS6

Wright, J.A., 2012, June. The integration of building information modeling and integrated project delivery into the construction management curriculum. In 2012 ASEE Annual Conference \& Exposition (pp. 25-1317).

Yadav, S., \& Kanade, G. (2018). Application of Revit as Building Information Modeling (BIM) for Integrated Project Delivery (IPD) to Building Construction Project-A Review. International Research Journal of Engineering and Technology, 11. www.irjet.net

Yin, 2003; Case Study Research: Design and Methods - Robert K. Yin - Google Books. (2003). Retrieved September 10, 2021, from https://books.google.co.uk/books?hl=en\&lr=\&id=FzawIAdilHkC\&oi=fnd\&pg=PR1\&dq=Yin,+R.+K.,+2 003.+Case+study+research:+design+and+methods.+London:+Sage\&ots=1_0P2hkS1u\&sig=4425C_o1Lq zf_Sg44ZK41QtpptA\#v=onepage\&q\&f=false

Zaini, A. A., Razali, A. W., Gui, H. C., Zaini, N., \& Tamjehi, S. D. (2020). Assessing Strategies of Building Information Modeling (BIM) Implementation in Sarawak Construction Industry. IOP Conference Series: Earth and Environmental Science, 498(1). https://doi.org/10.1088/1755-1315/498/1/012086 